\title{
RESPONSIVITAS DINAS LINGKUNGAN HIDUP DALAM PELAYANAN PERSAMPAHAN DI KOTA MAGELANG
}

\author{
Eny Boedi Orbawati, Retno Dewi Pramodia Ahsani \\ enyorbawati@yahoo.co.id
}

\begin{abstract}
Abstrak
Pertambahan jumlah penduduk perkotaan yang pesat berdampak terhadap peningkatan jumlah sampah yang dihasilkan. Salah satu permasalahan lingkungan hidup di Kota Magelang yang masih mendapat perhatian dari pemerintah adalah terkait pengelolaan sampah. Volume sampah yang dihasilkan di kota Magelang sangat besar yaitu 139,39 M (tahun 2014) meningkat menjadi 160,58 $\mathrm{M}^{3}$ (tahun 2015) dengan jumlah sampah terangkut sebesar 136,75 $\mathrm{M}^{3}$ setara $85,16 \%$ dan jumlah penduduk yang terlayani jaringan sampah sebesar $96 \%$.

Penelitian ini menggunakan pendekatan penelitian yang bersifat deskriptif yaitu mendeskripsikan dan menganalisis Responsivitas Dinas Lingkungan Hidup dalam Pelayanan Persampahan di Kota Magelang

Hasil penelitian ini menunjukan bahwa Dinas Lingkungan Hidup telah memiliki daya tanggap dalam pelayanan persampahan yaitu (1) daya tanggap potensial dalam penetapan kebijakan melibatkan stakeholder dan warga masyarakat. (2) Daya tanggap aktual, adanya pemenuhan keinginan masyarakat dalam manajemen pengelolaan persampahan (3) Daya tangap komitmen sumber daya dalam penanganan masalah persampahan dengan memperhatikan beberapa aspek yang terintergrasi yaitu aspek kelembagaan, teknis, pendanaan
\end{abstract}

Kata Kunci : Responsivitas, pelayanan persampahan, Lingkungan Hidup 


\begin{abstract}
Abstrack
The significant growth of urban population gives impact to the increasing waste production. One of main concern of Local Government of Magelang is the waste management. Waste volume in Magelang increasing significantly become 160,58 M (2015) with 136,75 M transported waste which equal to $.85,16 \%$ and $96 \%$ of population have been served by waste management network.

This paper uses descriptive approach. Main focus of research is Responsiveness of Environment Unit on Waste Management in Magelang.

Research's result explain that Environment Unit waste management responsiveness manifest at (1) Potential responsiveness, involving community to create waste management policy, (2) actual responsiveness, fulfilment of community interest in waste management, (3) Resources Commitment responsiveness in waste management by integrated institution aspect, technical, and funding.
\end{abstract}

Key Words : Responsiveness, Waste Management, Environment

\section{Pendahuluan}

Pertambahan jumlah penduduk di perkotaan yang pesat berdampak terhadap peningkatan jumlah sampah yang dihasilkan. Peningkatan jumlah sampah yang tidak diikuti oleh perbaikan dan peningkatan sarana dan prasarana pengelolaan sampah mengakibatkan permasalahan sampah menjadi komplek, antara lain sampah tidak terangkut dan terjadi pembuangan sampah liar, sehingga dapat menimbulkan berbagai penyakit, kota kotor, bau tidak sedap, mengurangi daya tampung sungai dan lain-lain

Jumlah penduduk Kota Magelang yang semakin meningkat mengakibatkan bertambahnya volume sampah. Disamping itu, pola konsumsi masyarakat memberikan kontribusi dalam menimbulkan jenis sampah yang semakin beragam. Selama ini sebagian besar masyarakat masih memandang sampah sebagai barang sisa yang tidak berguna, bukan sebagai sumber daya yang perlu dimanfaatkan. Masyarakat dalam mengelola sampah masih bertumpu pada pendekatan akhir (end of pipe) yaitu sampah dikumpulkan, diangkut, dan dibuang ke tempat pemrosesan akhir sampah. Padahal, timbunan sampah dengan volume yang besar di lokasi tempat pemrosesan akhir sampah berpotensi melepas gas metan ( $\mathrm{CH} 4$ ) yang dapat meningkatkan emisi rumah kaca dan memberikan kontribusi terhadap pemanasan global. Agar timbunan sampah dapat terurai melalui proses alam diperlukan jangka waktu yang lama dan 
diperlukan penanganan dengan biaya yang besar.

Paradigma pengelolaan sampah yang bertumpu pada pendekatan akhir sudah saatnya ditinggalkan dan diganti dengan paradigma baru pengelolaan sampah. Paradigma baru memandang sampah sebagai sumber daya yang mempunyai nilai ekonomi dan dapat dimanfaatkan, misalnya untuk energi, kompos, pupuk ataupun untuk bahan baku industri.

Pengelolaan sampah dilakukan dengan pendekatan yang komprehensif dari hulu, sejak sebelum dihasilkan suatu produk yang berpotensi menjadi sampah, sampai ke hilir, yaitu pada fase produk sudah digunakan sehingga menjadi sampah, yang kemudian dikembalikan ke media lingkungan secara aman. Pengelolaan sampah dengan paradigma baru tersebut dilakukan dengan kegiatan pengurangan dan penanganan sampah. Pengurangan sampah meliputi kegiatan pembatasan, penggunaan kembali, dan pendauran ulang, sedangkan kegiatan penanganan sampah meliputi pemilahan, pengumpulan, pengangkutan, pengolahan, dan pemrosesan akhir.

Salah satu permasalahan lingkungan hidup di Kota Magelang yang masih mendapat perhatian dari pemerintah adalah terkait pengelolaan sampah. Volume sampah yang dihasilkan di kota Magelang sangat besar yaitu 139,39 M (tahun 2014) meningkat menjadi $160,58 \mathrm{M}^{3}$ (tahun 2015) dengan jumlah sampah terangkut sebesar $136,75 \mathrm{M}^{3}$ setara $85,16 \%$ dan jumlah penduduk yang terlayani jaringan sampah sebesar $96 \%$.

Tabel 1.1 Jumlah Volume Produksi Sampah danSampah yang Ditangani

Tahun 2010-2015

\begin{tabular}{|l|l|l|l|l|l|l|l|}
\hline No & Uraian & 2010 & 2011 & 2012 & 2013 & 2014 & 2015 \\
\hline 1 & $\begin{array}{l}\text { Jumlah } \\
\text { volume } \\
\text { produksi } \\
\text { sampah } \\
\left(\mathrm{m}^{3} / \text { hari }\right)\end{array}$ & 207,18 & 193,94 & 208,85 & 217,92 & 139,39 & 160,58 \\
\hline 2 & $\begin{array}{l}\text { Jumlah } \\
\text { sampah yang } \\
\text { ditangani } \\
\left(\mathrm{m}^{3} / \text { hari) }\right.\end{array}$ & 170,06 & 164,78 & 172,45 & 186,72 & 118,54 & 136,75 \\
\hline & Persentase & $82,08 \%$ & $84,96 \%$ & $82,57 \%$ & $85,68 \%$ & $85,04 \%$ & $85,16 \%$ \\
\hline
\end{tabular}

Sumber : DLH 2015 
Melihat permasalahan tersebut di

Upaya mengurangi volume sampah yang dbuang ke TPA telah dilakukan dengan cara pengelolaan sampah dimulai dari sumbernya dengan sistem sistem 3R (Reduce, Reuse, Recycle). Namun kenyataan di lapangan volume sampah yang dihasilkan dan dibuang masih tinggi. Keterbatasan TPSA sampah dalam menampung sampah hari ini sudah melebihi daya tampung Di sisi lain lokasi TPSA Kota Magelang yang berada di wilayah Kabupaten Magelang sudah tidak dapat dikembangkan karena di dalam dokumen RTRW, lokasi tersebut telah ditetapkan sebagai wilayah hijau. Volume timbulan sampah cenderung meningkat setiap tahunnya. Oleh karena itu sampah menjadi masalah yang sangat besar terutama yang dihasilkan rumah tangga atau sampah domestik, sehingga membutuhkan peran serta masyarakat dalam pengelolaannya.

Berbagai upaya untuk mengatasi kondisi "darurat sampah" tersebut memang telah dilakukan oleh Pemerintah Kota Magelang. Namun dalam pelaksanaan di lapangan masih banyak menghadapi kendala. Sehubungan dengan hal tersebut, maka perlu dilakukan kajian ulang terhadap upayaupaya tersebut dan juga upaya-upaya baru agar permasalahan pengelolaan sampah yang dihadapi Pemerintah Kota Magelang dapat diatasi segera. atas, perlu responsivitas pemerintah daerah melalui Dinas Lingkungan Hidup dalam menangani persampahan. Tugas utama Pemerintah adalah melindungi dan memberikan rasa aman kepada masyarakat melalui kebijakan-kebijakan yang telah dirumuskannya. Dalam mengatasi permasalahan persampahan maka peran responsivitas birokrasi menjadi penting untuk bekerja dan tanggap di dalam perumusan kebijakan pengelolaan sampah. Birokrasi publik yang baik adalah birokrasi yang responsif, yaitu mempunyai daya tanggap yang tinggi dan cepat terhadap apa yang menjadi keluhan, masalah, aspirasi publik.

Responsivitas menyangkut kemampuan aparatur dalam menghadapi dan mengantisipasi aspirasi baru, dan pengetahuan baru. Birokrasi harus merespon secara cepat agar tidak tertinggal dalam menjalankan tugas dan fungsinya. Daya tanggap pemerintah atau birokrasi terhadap berbagai tuntutan dan kebutuhan masyarakat di era demokrasi saat ini semakin penting, karena tuntutan dan kebutuhan masyarakat semakin beragam dan dinamis. 
Metode Penelitian

Penelitian ini menggunakan metode penelitian kualitatif yang bersifat deskriptif analitik yaitu mendeskripsikan dan menganalisis Responsivitas Dinas Lingkungan Hidup dalam pelayanan persampahan. Penetapan fokus penelitian dalam pendekatan kualitatif sangat erat kaitannya dengan rumusan masalah dan tujuan penelitian. Permasalahan yang ditentukan merupakan pedoman dalam menentukan fokus penelitian. Mengacu pada latar pemikiran di atas maka fokus penelitian ini adalah : Mengungkapkan secara rinci Responsivitas Dinas Lingkungan Hidup dalam pelayanan persampahan .

Unit analisa dalam penelitian ini adalah fenomena tentang Responsivitas Dinas Lingkungan Hidup dalam pelayanan persampahan. Sedangkan individu sebagai unit analisa adalah Dinas Lingkungan Hidup, Kampung Organik, Bank Sampah dan tokoh masyarakat

Teknik yang digunakan dalam mencari informan ini adalah dengan teknik snowball. Hal ini berlangsung terus sampai informan jenuh atau datanya tersaturasi (saturated data). Dalam hal ini Spradley (1979) memberikan panduan tentang penelitian informan sebagai berikut : (1) apa yang diketahui informan tentang perilaku mereka, (2) konsep-konsep apa yang akan digunakan

informan

untuk

mengklasifikasikan pengalaman mereka, (3) bagaimana informan mendefinisikan konsep tersebut, (4) dengan cara apa informan menjelaskan pengalaman mereka, bagaimana peneliti menterjemahkan pengetahuan informan ke dalam deskripsi kebudayaan yang dapat dipahami oleh kolega peneliti.

\section{Hasil dan Pembahasan}

Daya tanggap pemerintah atau birokrasi ini dipandang sebagai fenomena penting dalam administrasi publik. Daya tanggap menunjuk pada kecepatan dan kemampuan pemerintah dalam menanggapi tuntutan masyarakat (Stivers, 1994: 364 - 368; Rosenbloom, 1989: 99; Vigoda, 2000: 175; 2002: 534).

Denhardt dan Denhardt (2007: 28), dalam upayanya membandingkan tiga perspektif administrasi publik (old public administration, new public management, dan new public service) mempertegas pentingnya persoalan daya tanggap pegawai pemerintah (public servants) terhadap kebutuhan masyarakat. Yaitu dengan mempertanyakan "to whom are public servants responsive?" dalam setiap perpsektif. Pada old public administration, pegawai pemerintah harus memenuhi kebutuhan clients dan constituents, dalam new public management memenuhi kebutuhan customers, dan pada new public 
service pemerintah bertanggungjawab memenuhi kebutuhan citizens. Begitu pentingnya persoalan daya tanggap dalam administrasi publik, menyebabkan Denhardt dan Denhardt (2007) maupun Osborne dan Gaebler (1992) mendorong organisasi publik meniru daya tanggap yang dimiliki oleh sektor swasta (private), guna meningkatkan kinerja yang efektif dan efisien, keadilan, tanggung jawab, dan akuntabilitas organisasi publik.

Gormley, Hoadley, dan Williams (1983: 709) mendefinisikan daya tanggap sebagai kemampuan pemerintah untuk menetapkan secara cepat isu-isu penting yang harus segera ditanggapi, mengatasi isu dan masalah secara nyata dengan berbagai tindakan, melalui penyediaan berbagai sumber daya. Oleh karenanya, Gormley, Hoadley, dan Williams (1983: 706 - 713) mengukur daya tanggap dalam tiga kategori, yaitu daya tanggap potensial, daya tanggap aktual, dan daya tanggap komitmen sumber daya. Pertama, daya tanggap potensial menunjuk pada sejauh mana pejabat pemerintah dengan para pemangku kepentingan menetapkan bersama nilai-nilai dan isu-isu prioritas yang akan ditangani. Tindakan ini dilakukan melalui proses dialog, guna mengidentifikasi berbagai masalah yang dirasakan oleh masyarakat. Berbagai masalah tersebut, kemudian dipersempit untuk memilih isu yang paling penting dan mendesak untuk ditangani. Kedua, daya tanggap aktual menunjuk pada sejauh mana pemerintah mampu memenuhi kebutuhan dan keinginan masyarakat secara nyata. Berbagai permasalahan, kebutuhan dan keinginan masyarakat yang telah dinyatakan dalam daya tanggap potensial kemudian secara cepat ditindaklanjuti melalui program-program atau kegiatan yang secara langsung dapat mengatasi persoalan tersebut. Ketiga, daya tanggap komitmen sumber daya menunjuk kepada dukungan sumber daya (finansial, manusia, peralatan dan fasilitas lainnya) guna mengatasi berbagai isu yang telah ditetapkan dalam daya tanggap aktual.

\section{Responsivitas Dinas Lingkungan Hidup}

\section{dalam pelayanan persampahan}

\section{Daya tanggap potensial}

Daya tanggap potensial dalam hal ini merupakan gambaran tentang sejauh mana pemerintah daerah dalam hal ini Dinas Lingkungan Hidup dengan para pihak pemangku kepentingan menetapkan bersama mengidentifikasi masalah persampahan, melibatkan stakeholders dalam pembahasan isuisu sampah dan mengembangan solusi alternatif yang sesuai dengan masalah persampahan (Gormley, Hoadley dan Williams, 1983). Berdasarkan hasil penelitian terlihat bahwa berdasarkan Undang-Undang Nomor 18 Tahun 2008 tentang Pengelolaan Sampah, Kota Magelang menetapkan Perda Nomor 10 Tahun 2013 tentang Pengelolaan Sampah. Di dalam 
Perda tersebut secara garis besar dijelaskan bahwa pengelolaan sampah bertujuan untuk meningkatkan kualitas lingkungan dan kesehatan masyarakat serta menjadikan sampah sebagai sumber daya.

Pemerintah Daerah bertugas untuk menjamin terselenggaranya pengelolaan sampah yang baik dan berwawasan lingkungan. Tugas Pemerintah Daerah tersebut meliputi 1) menumbuhkembangkan dan meningkatkan kesadaran masyarakat dalam pengelolaan sampah; 2) melakukan penelitian dan pengembangan teknologi pengurangan serta penanganan sampah; 3) memfasilitasi, mengembangkan dan melaksanakan upaya pengurangan, penanganan, dan pemanfaatan sampah; 4) melaksanakan pengelolaan sampah serta memfasilitasi sarana dan prasarana pengelolaan sampah; 5) memfasilitasi dan melakukan pengembangan atas manfaat yang dihasilkan dari pengelolaan sampah; 6) memfasilitasi penerapan teknologi spesifik lokal yang berkembang pada masyarakat setempat untuk menangani dan mengurangi sampah; dan 7) melakukan koordinasi antar Satuan Kerja Perangkat Daerah, masyarakat, dan dunia usaha agar terdapat keterpaduan dalam pengelolaan sampah.

Jadi, pengelolaan sampah tidak hanya menjadi tugas dan tanggung jawab Pemerintah Daerah saja melainkan juga menjadi tugas dan tanggungjawab masyarakat. Hal ini diperkuat dalam pasal 61 yang menyatakan bahwa masyarakat dapat berperan dalam menangani masalah pengelolaan sampah yang diselenggarakan oleh Pemerintah Daerah. Bentuk peran masyarakat dalam pengelolaan sampah meliputi 1) menjaga kebersihan lingkungan; 2) aktif dalam kegiatan pengurangan, pengumpulan, pemilahan, pengangkutan, dan pengolahan sampah; dan 3) pemberian saran, usul, pengaduan, pertimbangan, dan pendapat dalam upaya peningkatan pengelolaan sampah di wilayahnya. Bahkan Pemerintah Daerah akan memberikan insentif kepada perseorangan maupun lembaga atau badan usaha yang melakukan inovasi terbaik dalam pengelolaan sampah dan/atau pelaporan atas pelanggaran terhadap larangan.

Kegiatan pengangan sampah di Kota Magelang sudah sesuai dengan UU No 18 tahun 2008 tentang pengelolaan sampah yaitu meliputi pemilahan, pengumpulan, pengangkutan, pengolahan dan pemrosesan.

Berdasarkan realisasi pada RPJMD tahun 2015 urusan persampahan, capaian indikator dalam pelayanan bidang persampahan dapat dilihat sebagai berikut : 
Tabel 2. Realisasi Capaian Indikator RPJMD Kota Magelang Tahunn 2015 Urusan Persampahan

\begin{tabular}{|l|l|c|c|}
\hline No & \multicolumn{1}{|c|}{ Indikator Kinerja } & \multicolumn{2}{|c|}{$\mathbf{2 0 1 5}$} \\
\cline { 3 - 4 } & \multicolumn{1}{|c|}{ Target } & Realisasi \\
\hline $\mathbf{1 .}$ & Jumlah penduduk terlayani jaringan sampah & $94 \%$ & $\mathbf{9 5 \%}$ \\
\hline $\mathbf{2 .}$ & Persentasi (\%) penanganan sampah perkotaan & $95 \%$ & $\mathbf{8 5 \%}$ \\
\hline $\mathbf{3}$ & $\begin{array}{l}\text { Rasio penanganan sampah } \\
\text { (pengangkutan) }\end{array}$ & $\mathbf{9 5 \%}$ \\
\hline $\mathbf{4}$ & $\begin{array}{l}\text { Presentase penanganan sampah di TPSA } \\
\text { (pengelolaan sanitary landfiil }\end{array}$ & $100 \%$ & $\mathbf{1 0 0} \%$ \\
\hline $\mathbf{5}$ & JUmlah pengelolaan sampah terpadu & 5 & $\mathbf{2}$ \\
\hline
\end{tabular}

\section{Sumber : DLH 2016}

Berdasarkan data RPJMD Kota Magelang tersebut, realisasi capaian indicator urusan bidang persampahan tahun 2015 yang terealisasi dinataranya jumlah penduduk yang terlayani adalah $95 \%$. Jumlah volume sampah yang tertangani sebesar $85 \%$, rasio penanganan sampah perkotaan/pengangkutan 95\%, penanganan sampah di TPSA / pengelolaan sanitaru landfiil 100\%, serta pengolahan sampah terpadu terealisasi 2 TPST.

Jika melihat realisasi capaian indicator tersebut maka dapat disimpulkan bahwa Dinas Lingkungan Hidup sudah reesponsif terhadap pelayanan persampahan di Kota Magelang

\section{Daya Tanggap Aktual}

Daya tanggap aktual menunjuk pada sejauh mana pemerintah mampu memenuhi kebutuhan dan keinginan masyarakat secara nyata dalam tindakan-tindakannya. Berbagai permasalahan, kebutuhan dan keinginan masyarakat yang telah dinyatakan dalam daya tanggap potensial kemudian secara cepat perlu ditindaklanjuti melalui tindakan-tindakan atau program yang secara langsung dapat mengatasi persoalan tersebut (Esaiasson, Gilljam dan Persson 2016)

Hasil penelitian menunjukan bahwa Dinas Lingungan Hidup sudah menerapkan paradigm baru dalam pengelolaan sampah. Dalam paradigma baru pengelolaan sampah memandang sampah sebagai sumberdaya yang mempunyai manfaat, sedangkan pengelolaannya bertumpu pada pendekatan sumber (pendekatan hulu-hilir). Paradigma baru pengelolaan sampah meliputi siklus hidup sampah mulai dari hulu sejak sebelum dihasilkan suatu produk sampai ke hilir dan pada fase produk sudah digunakan dan 
menjadi sampah yang kemudian dikirim ke tempat pemrosesan akhir sampah untuk dikembalikan ke media lingkungan secara aman.

Konsep hirarki pengelolaan sampah ini juga lebih dikenal dengan istilah $3 \mathrm{R}$ atau Reduce, Reuse dan Recycle. Reduce (Mengurangi); berarti mengurangi jumlah sampah yang dihasilkan. Reuse (Memakai Kembali); sebisa mungkin pilihlah barangbarang yang bisa dipakai kembali. Hindari pemakaian barang-barang yang disposable (sekali pakai, buang). Recycle (Mendaur Ulang); sebisa mungkin, barang-barang yang sudah tidak berguna lagi, bisa didaur ulang Pengolahan sampah dengan paradigma baru, dibutuhkan peran dari berbagai pihak baik Pemerintah Daerah, stakeholder, dan yang terpenting adalah masyarakat yang merupakan penghasil sampah terbesar

Pengelolaan sampah adalah semua kegiatan yang dilakukan dalam menangani sampah sejak ditimbulkan sampai dengan pembuangan akhir. Secara garis besar, kegiatan di dalam pengelolaan sampah meliputi pengendalian timbulan sampah, pengumpulan sampah, transfer dan transport, pengolahan dan pembuangan akhir.

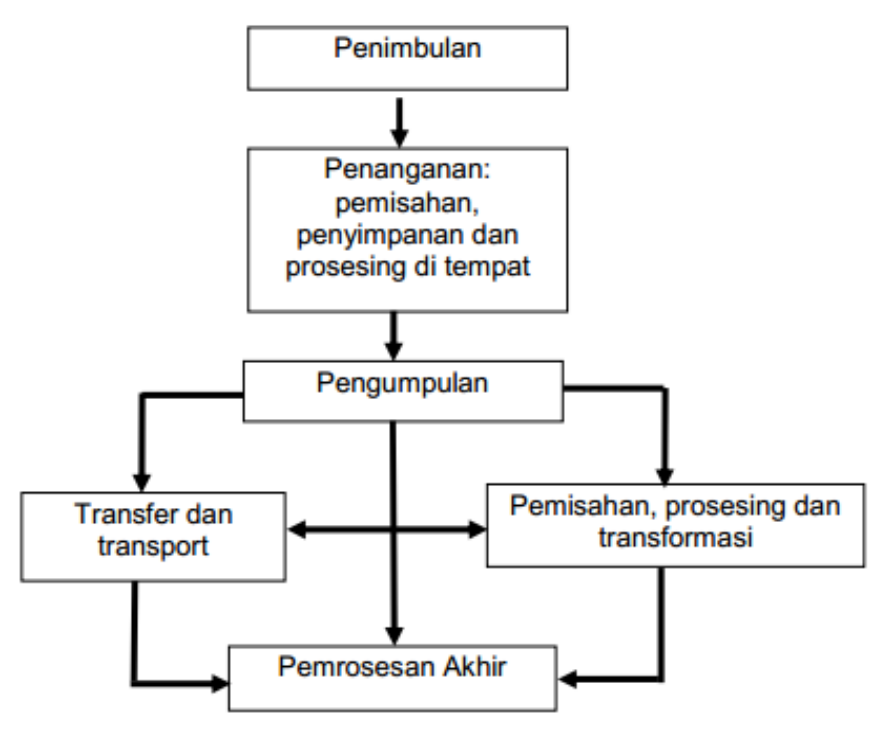

Gambar 1.

Faktor-faktor dalam pengelolaan sampah 
Secara umum pengelolaan sampah di kota Magelang dilakukan melalui 3 tahap kegiatan, yaitu: pengumpulan, pengangkutan dan pembuangan akhir. Secara sederhana tahapan-tahapan dari proses kegiatan dalam pengelolaan sampah sebagai berikut:

a) Pengumpulan diartikan sebagai pengelolaan sampah dari tempat asalnya sampai ke tempat pembuangan sementara sebelum menuju tahapan berikutnya. Pada tahapan ini digunakan sarana bantuan berupa tong sampah, bak sampah, peti kemas sampah, gerobak dorong maupun tempat pembuangan sementara. Untuk melakukan pengumpulan, umumnya melibatkan sejumlah tenaga yang mengumpulkan sampah setiap periode waktu tertentu.

b) Tahapan pengangkutan dilakukan dengan menggunakan sarana bantuan berupa alat transportasi tertentu menuju ke tempat pembuangan akhir/ pengolahan. Pada tahapan ini juga melibatkan tenaga yang pada periode waktu tertentu mengangkut sampah dari tempat pembuangan sementara ke tempat pembuangan akhir.

c) Pada tahap pembuangan akhir/ pengolahan, sampah akan mengalami pemrosesan baik secara fisik, kimia maupun biologis sedemikian hingga tuntas penyelesaian seluruh proses. Pengelolaan sampah, terutama di kawasan sekolahan, dewasa ini dihadapkan kepada berbagai permasalahan yang cukup kompleks. Permasalahan-permasalahan tersebut meliputi tinggi laju timbulan sampah yang tinggi.

\section{Daya Tanggap Komitmen Sumber Daya}

Daya tanggap komitmen sumber daya menunjuk kepada dukungan sumber daya (finansial, manusia, peralatan dan fasilitas lainnya) guna mengatasi berbagai isu yang telah ditetapkan dalam daya tanggap aktual.

Daya tanggap sumberdaya dalam penelitian ini dapat dilihat dari 4 aspek yaitu :

\section{a) Aspek Kelembagaan}

Pengelolaan persampahan di Kota Magelang terutama dilakukan oleh Dinas Lingkungan Hidup (DLH). Mekanisme pengelolaan sampah secara garis besar dibagi dalam 2 tahap, yaitu dari lingkungan ke TPS atau transfer Depo, dan dari TPS ke TPA. Pengangkutan sampah dari lingkungan permukiman secara umum dikelola secar 
a kolektif oleh masyarakat sendiri dengan menggunakan gerobak sampah.

\section{b) Aspek Teknis}

Prasarana persampahan yang ada di Kota Magelang meliputi bak sampah yang tersebar di seluruh wilayah Kota Magelang, serta TPS dan transfer depo yang umumnya terletak di tepi jalan-jalan utama dan di sekitar pusat-pusat kegiatan perekonomian. Sementara itu, tempat pembuangan akhir (TPA) masih memanfaatkan area/lahan di wilayah administrasi Kabupaten Magelang, tepatnya di wilayah Desa Banyuurip Kec. Tegalrejo. Pada TPA terjadi kerjasama antara Kota Magelang dengan Kabupaten Magelang yang dilakukan pendaurulangan sampah menjadi kompos yang dapat digunakan sebagai pupuk bagi masyarakat di Kabupaten Magelang.

\section{c) Aspek Pendanaan}

Pembiayaan dalam pengelolaan sampah di Kota Magelang bersumber dari dana APBD Kota Magelang melalui Dinas
Lingkungan Hidup yang selama ini bertanggungjawab dalam aspek persampahan. Selain itu juga didukung adanya retribusi dari masyarakat yang terlayani oleh sistem pengangkutan sampah Kota Magelang.

\section{d) Aspek Peran Serta Masyarakat}

Masyarakat Kota Magelang memiliki peran yang sangat positif dalam pengelolaan sampah. Pemerintah daerah telah mendorong partisipasi aktif masyarakat melalui program penyuluhan serta program 3R. di Kota Magelang sendiri pengelolaan sampah berbasis masyarakat tercipta dua program unggulan yaitu Kampung Organik dan Bank sampah. Dimana kondisinya saat ini cukup aktif dan tersebar di seluruh wilayah Kota Magelang. Kegiatan tersebut memiliki peran signifikan dalan mengurangi jumlah timbulan sampah dan dapat menjadi sumber peningkatan ekonomi masyarakat. 


\section{Kesimpulan}

Sampah telah menjadi permasalahan di Kota Magelang dengan laju produksi sampah yang terus bertambah setiap tahun berbanding terbalik dengan laju program pengurangan sampah dan kapasitas TPSA yang semakin berkurang. Hasil penelitian menunjukkan bahwa Dinas Lingkungan Hidup telah mampu mengidentifikasi masalah persampahan Kota Magelang secara komprehensif. Dalam mengatasi permasalahan persampahan, Pemerintah Daerah khususnya Dinas Lingkungan Hidup telah melibatkan seluruh stakeholders terkait, termasuk unsur masyarakat, Swasta dan pemerintah dalam penanganan masalah persampahan. Di samping itu, Pemerintah Kota Magelang telah memiliki otoritas dan regulasi dalam menetapkan kebijakan persampahan sehingga telah responsif terhadap masalah pelayanan persampahan. Oleh sebab itu, berdasarkan hasil penelitian dan pembahasan dapat disimpulkan bahwa Dinas Lingkungan Hidup Kota Magelang telah responsif dalam pelayanan persampahan sisi daya tanggap potensialnya dan daya tanggap aktual

Penelitian ini hanya berfokus pada masalah responsivitas Dinas LIngkungan Hidup pelayanan persampahan. Untuk melihat bagaimana partisipasi masyarakat terhadap penanganan permasalah sampah sehingga bisa mengurangi timbunan sampah dari sumbernya maka perlu dilakukan penelitian lanjutan tentang partisipasi masyarakat dalam mengatasi masalah sampah rumah tangga. 


\section{Referensi}

Jurnal :

Esaiasson, Peter, Mikael Gilljam \& Mikael Persson. 2016. "Responsiveness Beyond Policy Satisfaction: Does It Matter to Citizens?". Comparative Political Studies: $1-27$.

Eron Vegoda 2002, From Responsiveness to Collaboration: Governance, Citizens, and the Next Generation of Public Administration. University of Haifa, Israel

Gormley, William T., Jr.: Hoadlcy,John; and Williams,Charles.1983. Potential Responsiveness in the Bureauaacy: Views of Public Utility Regulation. American Political Science Review.

Orbawati, Eny, 2016. The Responsiveness Bureaucracy within the Governance Policy of Dieng Plateau Conservation, Proceedings of the International Conference on Public Management.
Orbawati, Eny, 2018. The Responsiveness of Local Government onto Public Service: The Case of the Conflict Area of Boundary Affirmation among County and Magelang City, The Social Sciences. Volume: 13 | Issue: 6

Buku :

Anderson, James E, 1979. Public Policy, second edition. Holt, Rinehart and Winston

Denhardt, Janer V, and Robert B. Denhardt. 2003. The New Public Service :Serving Not Steering. Armonk, N.Y : M.E.Sharpe

Spradley, J.P. The Ethnographic Interview, (New York: Holt, Rinehart \& Winston, 1979

Suwitri, Sri. 2011. Jejaring Kebijakan Dalam Perumusan Kebijakan. SuatuKajian Tentang Perumusan Kebijakan Penanggulangan Banjir dan Rob Pemerintah Kota Semarang.Badan Penerbit Universitas Diponegoro 